\title{
Pengaruh Kualitas Website (Webqual 4.0) Terhadap Penggunaan Kembali
}

\author{
Arifyan Dwi Prayogo ${ }^{1 *}$ dan Ma'mun Sutisna ${ }^{2}$ \\ ${ }^{1}$ Administrasi Niaga, Politeknik Negeri Bandung, Indonesia \\ ${ }^{2}$ Administrasi Niaga, Politeknik Negeri Bandung, Indonesia
}

\begin{abstract}
:
This study assesses the effect of Tokopedia website quality using WebQual 4.0 on repeat usage of website services. Tokopedia growth until the end of 2016 made them as a refresher in C-to$C$ Commerce which has the modern services that gather buyers and sellers without face to face interaction so website platform of Tokopedia has important role in Tokopedia business activity. The research method using descriptive analysis with quantitative approach. Data analysis method used descriptive analysis, classical assumption test, correlation analysis, simple regression analysis, and hypothesis test. Sample on this research are 200 respondents which are tokopedia users. Based on data results, Tokopedia website quality is good and repeat usage is in fair category. This research conclude website quality influence of repeat usage $(40,6 \%)$.
\end{abstract}

Keywords: e-commerce, repeat usage, Tokopedia, webqual

\begin{abstract}
Abstrak:
Penelitian ini menilai pengaruh kualitas website Tokopedia dengan metode Webqual 4.0 terhadap repeat usage layanan website (studi pengguna website Tokopedia). Pertumbuhan Tokopedia hingga akhir tahun 2016 membuat perusahaan tersebut sebagai penyegar di ranah bisnis C-to-C Commerce yaitu layanan modern tersebut mempertemukan pembeli dan penjual tanpa bertatap muka sehingga pentingnya platform website sebagai pemegang peran penting dalam kegiatan bisnis Tokopedia. Metode penelitian yang digunakan adalah deskriptif dengan pendekatan kuantitatif. Metode analisis data yang digunakan yaitu analisis deskriptif, uji asumsi klasik, analisis korelasi, analisis regresi sederhana, dan uji hipotesis. Sampel penelitian ini sebanyak 200 responden yang seluruhnya adalah pengguna website Tokopedia. Hasil penelitian menunjukkan kualitas website pada kategori baik dan penggunaan kembali dalam kategori cukup. Kesimpulan dari penelitian ini yaitu terdapat pengaruh kualitas website terhadap penggunaan kembali sebesar 40,6\%.
\end{abstract}

Kata Kunci: e-commerce, penggunaan kembali, Tokopedia, Webqual

\section{PENDAHULUAN}

Berkembangnya inovasi teknologi informasi terutama pada segi layanan karena penetrasi internet yang cepat berkembang dan masyarakat yang saat ini dapat mudah mengakses dalam cakupan

\footnotetext{
*Email korespondensi:

Arifyan Dwi Prayogo

Arifyandwip@gmail.com
}

area yang cukup luas, dengan hal tersebut persaingan usaha semakin bersaing semakin ketat dan semakin beragam dari segi produk maupun layanan yang berbasiskan internet. Pada masa kini internet sukses membawa perubahan pada masyarakat dalam berbagai aspek dalam kehidupan sehari-hari. Menurut Asosiasi Penyedia Jasa Internet Indonesia (APJII) di tahun 2016 pengguna internet di Indonesia

Jurnal Riset Bisnis \& Investasi

Vol. 3, No. 2, Agustus 2017

ISSN 2460-8211 
mencapai 132.7 Juta orang yang merupakan kenaikan signifikan dari tahun 2014 yang berkisar $51.8 \%$ dari data yang dirilis pada tahun tersebut. Dalam hasil tersebut juga $53,6 \%$ pengguna aktif internet berusia diantara 25 hingga 40 tahun, $28 \%$ berusia diatas 45 tahun dan $18,4 \%$ berusia diantara 10 hingga 24 tahun. Aktivitas pada penggunaan internet tersebut membentuk gaya hidup online dan perubahan pola konsumsi pada masyarakat, seperti kegiatan berbelanja yang dulunya hanya melakukan pembelian melalui toko fisik, sekarang dilakukan secara online.

Jumlah pengguna internet yang semakin meningkat secara signifikan jika dibandingkan pada tahun 2014, kenaikan pengguna internet yang semula pada 2014 sebesar 88 juta dan pada tahun 2016 meningkat hingga 132 juta pengguna internet. Hal ini juga sebagai potensi dalam mengembangkan penggunaan internet sebagai promosi, transaksi dan jual beli. Dengan komposisi pengguna internet yang mayoritas adalah pekerja dan hal tersebut.

Proses jual-beli yang pada awalnya mengharuskan untuk bertatap muka, sekarang dengan menggunakan gadget yang sudah terintegrasi dengan teknologi internet. Dengan efektifitas akses terhadap barang tersebut menjadi pengguna akan lebih mudah mencari barang yang ia inginkan kapanpun dan dimanapun ia berada.

E-commerce adalah kegiatan melakukan transaksi bisnis secara online melalui media internet dan perangkatperangkat yang terintregasi dengan internet (Laudon, 2014). E-commerce merupakan perdagangan elektronik yang terdapat di lingkungan masyarakat sebagai salah satu upaya untuk memenuhi kebutuhan manusia dengan cara yang lebih efektif dan efisien. Menurut APJII 2016 yang dikutip dalam laporan tahunan Tech Startup Daily social, sebanyak $47,6 \%$ penggunan internet memilih untuk menggunakan sebagai gadget yang dipilih untuk berselancar internet dan dengan kenaikan penggunaan internet yang signifikan, menurut survei TNS/Google Smartphone Research Indonesia pada tahun 2014 penetrasi pengguna smartphone sebesar $28 \%$ dengan jumlah penduduk Indonesia dan pada tahun 2016 mengalami kenaikan hingga 43\% yang dibandingkan dengan jumlah penetrasi pengguna smartphone pada tahun 2014. Hal ini penggunaan internet terutama penggunaan internet dalam keseharian pada smartphone semakin meningkat dan menunjukkan bahwa pasar e-commerce di Indonesia terbilang sangat prospektif dimana pengguna internet sudah dapat melakukan selancar pada internet di waktu kapanpun dan dimanapun mereka bereda, mengingat hal tersebut ditunjang oleh semakin bertumbuhnya jumlah pengguna internet aktif di Indonesia.

Hasil survei yang dilakukan oleh We Are Social dan Hootsuite mengemukakan bahwa penetrasi penggunaan e-commerce di Indonesia masih terbilang rendah dengan persentase $41 \%$ dibandingkan dengan jumlah global, hal tersebut menjadi tantangan besar bagi pelaku e-commerce dan juga sebagai peluang dalam memenangkan dalam persaingan dalam menyediakan portal belanja yang nyaman dan dapat digunakan oleh seluruh lapisan masyarakat. Dengan potensi yang besar tersebut menyebabkan banyaknya situs e-commerce yang bermunculan dan terus berkembang.

Laudon (2014) dalam bukunya, membagi e-commerce menjadi lima jenis, yaitu: business-to-consumer (B2C), business-to-business (B2B), costumer-tocostumer $(C 2 C)$, peer-to-peer $(P 2 P)$, mobile commerce (M-Commerce). Salah satu bentuk e-commerce yang banyak dikenal oleh masyarakat Indonesia adalah C2C (Customer to Costomer) atau lebih akrab dipanggil sebagai situs jual beli. C2C e-commerce memungkinkan penggunanya 
untuk saling menjual dan membeli produk atau jasa melalui sebuah marketplace (Laudon, 2014). Ciri utama C2C adalah bahwa transaksi jual-beli dilakukan oleh sesama pengguna, sedangkan penyedia marketplace menjadi perantara dan penyedia layanan.

Berkembangnya kegiatan transaksi yang dilakukan dengan online, penggunan tidak saja dimudahkan mengakses keperluan yang ingin dipenuhi namun pengguna juga dapat secara aktif membandingkan layanan pada situs manakah yang akan menarik untuk dikunjungi untuk berbelanja online.

Barnes (2002) Webqual merupakan sebuah pengukuran suatu kualitas website berdasarkan persepsi dari pengguna akhir website tersebut. Webqual adalah pengembangan dari teori e-servqual dimana teori tersebut merupakan pengukuran suatu layanan jasa dengan melihat persepsi dari kualitas layanan yang diberikan oleh suatu organisasi terhadap konsumen dari layanan tersebut.

Kemudahan akses dan berkembangnya layanan website jual beli online pada saat ini, persaingan yang kompetitif dari setiap layanan yang disuguhkan kepada pengguna. Pada 2016, Top Brand merilis hasil survei mengenai layanan berdasarkan popularity brand index.

Tabel 1 Popularity Brand Index Situs Ecommerce Berdasarkan Online Shop Barang Elektronik Tahun 2016

\begin{tabular}{|c|c|c|}
\hline $\begin{array}{c}\text { Rank of } \\
\text { Popoular }\end{array}$ & E-commerce & PBI \\
\hline 1 & Lazada & $29,3 \%$ \\
\hline 2 & OLX & $27,7 \%$ \\
\hline 3 & Tokopedia & $11,4 \%$ \\
\hline 4 & Bukalapak & $6,8 \%$ \\
\hline 5 & Bhineka & $4,1 \%$ \\
\hline 6 & Blibli & $4,0 \%$ \\
\hline 7 & Elevania & $3,7 \%$ \\
\hline 8 & Elekronic-city.com & $2,6 \%$ \\
\hline
\end{tabular}

Sumber: Top Brand Award (2016)
Tabel 2 Popularity Brand Index Situs Ecommerce Berdasarkan Jual Beli Online Tahun 2016

\begin{tabular}{|c|c|c|}
\hline $\begin{array}{c}\text { Rank of } \\
\text { Popoular }\end{array}$ & E-commerce & PBI \\
\hline 1 & OLX & $44,5 \%$ \\
\hline 2 & Lazada & $19,9 \%$ \\
\hline 3 & Tokopedia & $12,1 \%$ \\
\hline 4 & Bukalapak & $11,8 \%$ \\
\hline 5 & Elevania & $1,6 \%$ \\
\hline 6 & Kaskus & $0,8 \%$ \\
\hline
\end{tabular}

Sumber: Top Brand Award (2016)

Dari hasil survey yang dilakukan oleh Top-Brand dalam ketiga kategori tersebut pada tahun 2016 menunjukkan bahwa adanya persaingan yang sangat sengit dalam mencapai target merek yang dikenal dalam belanja online barang elektronik. Dalam hal ini terdapat gap yang cukup besar dan Tokopedia mendapat predikat yang cukup pada popularitas merek antara website Tokopedia dengan website e-commerce lainnya.

Tabel 3 Popularity Brand Index Situs Ecommerce Berdasarkan Online Shop Fashion Tahun 2016

\begin{tabular}{|c|c|c|}
\hline $\begin{array}{c}\text { Rank of } \\
\text { Popoular }\end{array}$ & E-commerce & PBI \\
\hline 1 & Zalora & $40,5 \%$ \\
\hline 2 & Lazada & $24,1 \%$ \\
\hline 3 & OLX & $8,7 \%$ \\
\hline 4 & Tokopedia & $4,4 \%$ \\
\hline 5 & Blibli & $3,3 \%$ \\
\hline
\end{tabular}

Sumber: Top Brand Award (2016)

Berdasarkan uraian atas, peneliti tertarik untuk melakukan kajian terhadap perusahaan Tokopedia terutama di area Bandung. Dengan judul "Pengaruh kualitas website terhadap repeat usage dengan model webqual di tokopedia (studi kasus pengguna website tokopedia)".

\section{KAJIAN LITERATUR \\ E-Commerce}

Turban (2004) mendefinisikan Perdagangan elektronik (E-commerce) adalah proses dari pembelian, penjualan, atau paertukaran produk, jasa, dan informasi melalui jaringan komputer, disertai internet. Laudon (2014) $e$ -

Jurnal Riset Bisnis \& Investasi 
commerce menghubungkan penggunaan internet dan web untuk transaksi binis. Lebih sederhananya, e-commerce memudahkan transaksi perdagangan menjadi digital antara organisasi dengan individu. Transaksi tersebut terjadi pada internet dan web.

Turban (2004) Dalam perdagangan elektronik dapat didefinisikan kedalam beberapa perspektif.

1. Komunikasi (Communication).

2. Perdagangan (Commercial)

3. Proses Bisnis (Business Process).

4. Jasa (Service).

5. Pembelajaran (Learning).

6. Kolaborasi (Collaboration).

7. Komunitas (Community). Klasifikasi umum dari suatu $e$ commerce dalam Turban (2004) yaitu beberapa hal berikut:

1. Business to business (B2B).

2. Business to consumer (B2C)

3. Business to business to consumer (B2B2C)

4. Consumer to business (C2B).

5. Consumer to consumer $(\mathrm{C} 2 \mathrm{C})$.

6. Mobile Commercae $(M-$ Commerce).

\section{Kualitas Website}

Barnes (2002) Webqual merupakan sebuah metode pengukuran suatu kualitas website berdasarkan persepsi dari pengguna akhir website tersebut.

Simamarta (2009:249) situs web pada umumnya dievaluasi dari sudut pandang pengguna. Oleh Karena itu, kualitas eksternalnya harus dipertimbangkan. Ada beberapa alasan untuk kualitas ini, diaantaranya :

1. Evolusi teknologi yang cepat

2. Campuran (banyaknya) teknologi

3. Kemudahan dalam penulisan HTML

4. "Toleransi" browser yang menampilkan kode halaman yang tidak benar.
Mitch (2003) dalam mengukur kualitas website dapat digunakan metode 2qcv3q yang dapat dijabarkan menjadi;

1. qvis/quis (identitas)

2. qvid/cuid (konten)

3. cvr/cur (pelayanan)

4. vbi/ubi (lokasi)

5. qvando/quabdo (pemeliharaan),

6. qvomodo/quomodo (kegunaan)

7. qvbvs avxiliis/quibus auxiliis (feasibilitas).

Loiacono, (2007) mengembangkan metode Webqual dan memperkenalkan Webqual $^{\mathrm{TM}}$, sebuah ukauran kualitas website dengan 12 dimensi didasarkan pada tinjauan literatur yang luas dan wawancara dengan desainer dan pengunjung website. Lima kategori umum kualitas website yang didapatkan dari kajian literatur dan eksplorasi penelitian Loicono, dkk. (2007), yaitu: ease of use, usefulness, entertaainment, complementary relationship, dan customer service.

Pada penilaian kualitas menggunakan metode Webqual 4.0 Barnes (2002) terdapat tiga dimensi utama Webqual yaitu:

1. Usability Quality

2. Information Quality

3. Service Interaction Quality)

\section{Penggunaan Kembali}

Lovelock (2007) penggunaan kembali merupakan keputusan pelanggan untuk secara suka rela terus berlangganan dengan perushaan tertentu dalam jangka panjang, dengan membeli dan menggunakan. Adanya kepuasan pada layanan yang digunakan menjadi faktor utama keberhasilan suatu bisnis.

Loyalitas merupakan wujud perilaku dari unit-unit pengambilan keputusan untuk melakukan pembelian yang teratur terhadap barang atau suatu jasa yang dipilih dalam waktu yang lama (Griffin, 2005:4). Menurut Parasuraman (dalam Sangaji dan Sopiah, 2013) bahwa 
"loyalitas pelanggan dalam konteks pemasaran jasa sebagai respon yang terkait erat dengan ikrar atau janji untuk memegang teguh komitmen yang mendasari kontinuitas relasi dan janji untuk memegang teguh komitmen yang mendasari kontinuitas relasi, dan biasanya tercermin dalam pembelian berkelanjutan dari penyedia jasa yang sama atas dasar dedikasi dan kendala pragmatis".

Dimensi Loyalitas menurut Griffin (2005) menyatakan bahwa konsumen memiliki karakteristik sebagai berikut:

1. Melakukan pembelian secara teratur (repeat purchase).

2. Melakukan pembelian di semua lini produk atau jasa (purchase across product and service lines).

3. Merekomendasi produk lain (referrals).

4. Menunjukkan kekebalan dari daya Tarik produk sejenis dari pesaing (retention).

Flavia (2005) mengemukakan beberapa kategori dalam melakukan pengukuran loyalitas pada website, beberapa kategori tersebut adalah:

1. Pengunjungi website ini dibandingkan lainnya dengan kategori yang sama.

2. Website tersebut merupakan laman favorit saya untuk berbelanja online baik produk maupun jasa.

3. Frekuensi berkunjung website yang sejenis yang menawarkan produk yang sama lebih rendah.

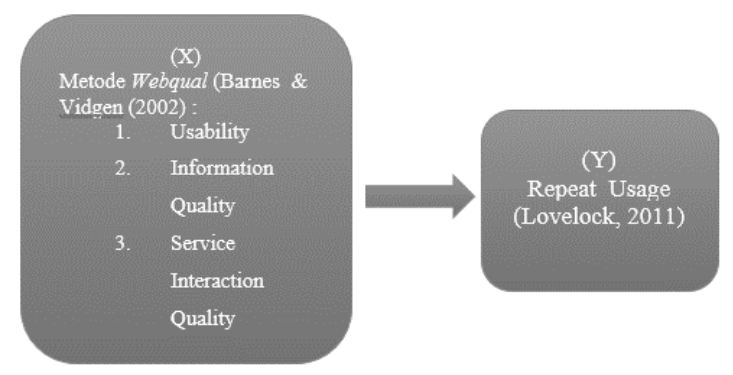

Gambar 1 Kerangka Pemikiran

Berdasarkan pembahasan dalam latar belakang, landasan teori, dan kerangka berpikir, maka hipotesis yang diajukan untuk diuji kebenarannya dalam penelitian ini, yaitu:

Ho : Kualitas website tidak berpengaruh secara positif dan signifikan terhadap penggunaan kembali pada pengguna website Tokopedia.

Ha : Kualitas website berpengaruh secara positif dan signifikan terhadap penggunaan kembali pada pengguna website Tokopedia.

\section{METODE PENELITIAN}

Arikunto (2010:3) penelitian deskriptif adalah penelitian untuk menyelidiki keadaan, kondisi atau hal lainlain yang sudah disebutkan, yang hasilnya dipaparkan dalam bentuk laporan penelitian. Tujuan penelitan ini yaitu mengetahui kualitas website Tokopedia, penggunaan kembali website, dan pengaruh kualitas website terhadap penggunaan kembali website Tokopedia menggunaakan model Webqual 4.0.

Teknik sampling yang digunakan adalah non probability sampling dengan cara pengambilan sampel menggunakan purposive sampling. Subjek penelitian ini yaitu pengguna Tokopedia sebesar 200 responden. Jumlah sampel minimal yang dibutuhkan menurut Malhotra et al (2007) adalah minimal 200 untuk penelitian berjenis problem solving atau pemecahan masalah, maka jumlah sampel penelitian ditetapkan 200.

\section{HASIL DAN PEMBAHASAN}

Hasil statistik deskriptif pada tabel 5, memperlihatkan bahwa nilai rata-rata kualitas website yang dilakukan kepada pengguna Tokopedia sebesar 3,72. Berdasarkan tabel Saunders (2016) intepretasi nilai hasil analisis deskriptif, angka tersebut berada pada interval 3,40 4,20. Hasil tesebut dapat diintepretasikan bahwa kualitas website Tokopedia 
dikategorikan baik oleh pengguna website Tokopedia.

Standar deviasi pada variabel kualitas website ini sebesar 0,605, dapat diartikan bahwa tingkat variansi jawaban sebesar $16,2 \% \frac{0,605}{3,72} \times 100$. Hal ini menunjukkan bahwa variasi jawaban dari rseponden terhadap pertanyaan yang diberikan adalah kecil. Santoso (2012) standar deviasi yang kurang dari $20 \%$ menunjukkan adanya variasi yang kecil. Dengan demikian, secara umum responden menjawab pertanyaan dengan jawaban yang serupa.

Tabel 4 Karakteristik Responden

\begin{tabular}{|c|c|}
\hline Jenis Kelamin & Presentase \\
\hline Laki-laki & $25 \%$ \\
\hline Perempuan & $75 \%$ \\
\hline Umur & \\
\hline 18-21 Tahun & $59 \%$ \\
\hline $22-25$ Tahun & $34 \&$ \\
\hline 26-30 Tahun & $4 \%$ \\
\hline$>30$ Tahun & $3 \%$ \\
\hline Pekerjaan & \\
\hline Pelajar/Mahasiswa & $59 \%$ \\
\hline Pegawai Stawasta & $34 \%$ \\
\hline Wiraswasta & $4 \%$ \\
\hline PNS & $3 \%$ \\
\hline Lainnya & $7 \%$ \\
\hline Penghasilan & \\
\hline$<1$ Juta & $45 \%$ \\
\hline 1 - 2 Juta & $34 \%$ \\
\hline 2 - 3 Juta & $8 \%$ \\
\hline 3 - 4 Juta & $4 \%$ \\
\hline$>$ 4 Juta & $9 \%$ \\
\hline Terakhir Mengakses & \\
\hline 1 Minggu & 27 \\
\hline 1 Minggu sd 1 Bulan & 20 \\
\hline 1 Bulan sd 3 Bulan & 18 \\
\hline$>$ 3 Bulan & 35 \\
\hline
\end{tabular}

Sumber : Olah Data (2017)

Tabel 5 Analisis Deskriptif

\begin{tabular}{|c|c|c|c|}
\hline $\begin{array}{c}\text { Nama Dimensi/ } \\
\text { Variabel }\end{array}$ & $\mathrm{N}$ & Mean & $\begin{array}{c}\text { Std. } \\
\text { Deviation }\end{array}$ \\
\hline $\begin{array}{c}\text { Kualitas } \\
\text { Website }\end{array}$ & $\mathbf{2 0 0}$ & $\mathbf{3 , 7 2}$ & $\mathbf{0 , 6 0 5}$ \\
\hline Usability & 200 & 3,80 & 0,636 \\
\hline $\begin{array}{c}\text { Information } \\
\text { Quality }\end{array}$ & 200 & 3,67 & 0,626 \\
\hline
\end{tabular}

Jurnal Riset Bisnis \& Investasi

Vol. 3, No. 2, Agustus 2017

ISSN 2460-8211

\begin{tabular}{|c|c|c|c|}
\hline $\begin{array}{c}\text { Service } \\
\text { Information } \\
\text { Quality }\end{array}$ & 200 & 3,58 & 0,668 \\
\hline $\begin{array}{c}\text { Penggunaan } \\
\text { Kembali }\end{array}$ & 200 & 3,14 & 0,761 \\
\hline
\end{tabular}

Dimensi kegunaan (usability) menunjukkan bahwa nilai rata-rata (mean) dalam kategori baik dengan hasil sebesar 3,80 karena berada pada interval nilai ratarata dalam kategori baik/tinggi yang artinya kegunaan pada kualitas website pada Tokopedia memiliki nilai pada tingkat yang baik. Dimensi kegunaan (usability) merupakan nilai tertinggi dalam hasil ratarata variabel kualitas website dibandingkan dimensi lainnya. Hal tersebut mengindikasikan bahwa kegunaan website Tokopedia dinilai baik berdasarkan asumsi pengguna website Tokopedia.

Dimensi kualitas informasi (information quality) menunjukkan bahwa nilai rata-rata (mean) dalam kategori baik dengan hasil sebesar 3,67 karena berada pada interval nilai rata-rata berada dalam kategori baik/tinggi yang artinya kualitas informasi pada website pada Tokopedia memiliki nilai pada tingkat yang baik. Dimensi kualitas informasi merupakan nilai selanjutnya yang dalam kategori tinggi setelah dalam hasil rata-rata variabel kualitas website dibandingkan dimensi lainnya. Hal tersebut mengindikasikan bahwa kualitas informasi yang tersaji dalam website Tokopedia dinilai baik berdasarkan asumsi pengguna website Tokopedia.

Dimensi kualitas interaksi layanan menunjukkan bahwa nilai rata-rata (mean) dalam kategori baik dengan hasil sebesar 3,58 karena terdapat pada interval nilai ratarata dalam kategori baik/tinggi yang artinya kualitas interaksi layanan website pada Tokopedia memiliki nilai pada tingkat yang baik/tinggi. Dimensi kualitas interaksi layanan merupakan nilai terendah dalam hasil rata-rata pada variabel kualitas website dibandingkan dimensi lainnya. Walaupun terendah, dimensi ini mencatat 
hasil rata-rata yang baik. Hal tersebut mengindikasikan bahwa kualitas interaksi layanan website Tokopedia dinilai baik berdasarkan asumsi pengguna website Tokopedia.

Hasil statistik deskriptif pada tabel 5, dapat dilihat bahwa nilai rata-rata penggunaan kembali yang dilakukan kepada pengguna Tokopedia sebesar 3,14. Berdasarkan tabel Saunders (2016) intepretasi nilai hasil analisis deskriptif, angka tersebut berada pada interval 2,60 3,39. Hasil tersebut dapat diintepretasikan bahwa penggunaan kembali Tokopedia dikategorikan cukup oleh pengguna website Tokopedia.

Standar deviasi pada variabel kualitas website ini sebesar 0,761 yang dapat diartikan bahwa tingkat variansi jawaban sebesar 24,2 \% $\frac{0,761}{3,14} \times 100$. Hal ini menunjukkan bahwa variasi jawaban dari responden terhadap pertanyaan yang diberikan adalah besar.

\section{Analisis Korelasi dan Regresi}

Tabel 6 Uji Korelasi

\begin{tabular}{|ll|r|r|}
\hline & & \multicolumn{1}{|c|}{$\begin{array}{c}\text { Kualltas } \\
\text { Webslte }\end{array}$} & $\begin{array}{c}\text { Penggunaan } \\
\text { Kemball }\end{array}$ \\
\hline Kualitas Website & Pearson Correlation & 1 & .637 \\
& Sig. (2-tailed) & & .000 \\
& $\mathrm{~N}$ & 200 & 200 \\
\hline Penggunaan Kembali & Pearson Correlation & .637 & 1 \\
& Sig. (2-tailed) & .000 & \\
& $\mathrm{~N}$ & 200 & 200 \\
\hline
\end{tabular}

Dari penelitian ini diperoleh hasil korelasi antara dua variabel sebesar 0,637 dimana hasil tersebut dapat diindikasikan bahwa hubungan kedua variabel tersebut memiliki hubungan yang kuat dan positif, sesuai dengan yang dikemukakan Saunder (2016) inteprestasi nilai korelasi yaitu bahwa nilai yang dihasilkan pada penelitian ini berada pada rentang nilai $0,351-0,800$ yang mengindikasikan adanya pengaruh yang kuat dan positif pada kedua variabel penelitan ini.

Tabel 7 Analisis Regresi Sederhana

\begin{tabular}{|c|c|c|c|}
\hline \multirow{2}{*}{ Model } & $\begin{array}{c}\text { Unstandardiz } \\
\text { ed }\end{array}$ & $\begin{array}{c}\text { Standar } \\
\text { dized }\end{array}$ & Sig. \\
\cline { 2 - 2 } & $\mathrm{B}$ & . \\
\hline
\end{tabular}

\begin{tabular}{|c|c|c|c|}
\hline Constant & 0,45 & & 0,987 \\
\hline $\begin{array}{c}\text { Kualitas } \\
\text { Website }\end{array}$ & 0,381 & 0,637 & 0,000 \\
\hline
\end{tabular}

Melihat kolom pada unstandardized coefficient nilai konstanta (a) sebesar 0,045 dengan koefisien regresi (b) sebesar 0,381. Maka persamaan regresi yang dihasilkan adalah $\mathrm{Y}=0,045+0,381 \mathrm{X}$.

\section{Uji Hipotesis}

\begin{tabular}{|c|c|c|} 
Tabel 8 Uji F \\
\begin{tabular}{|c|c|c|}
\hline Model & F & Sig. \\
\hline Regresion & 135,154 & 0,000 \\
\hline
\end{tabular}
\end{tabular}

Diketahui bahwa $\mathrm{f}$ hitung dari kualitas website memilki nilai thitung sebesar 135,154 . sementara untuk nilai signifikansi sebesar 0,000 serta df $=200-2=198, t_{\text {tabel }}$ yang diperoleh adalah sebesar 3,89. Diketahui tingkat sehingga diperoleh nilai signifikansi lebih kecil dari nilai probabilitas $(0,050)$. Dapat disimpulkan bahwa $\mathrm{H}_{\mathrm{a}}$ diterima dan terdapat pengaruh positif dan signifikan secara simultan kualitas website terhadap penggunaan kembali pada website Tokopedia.

Tabel 9 Uji T

\begin{tabular}{|l|c|c|}
\hline \multicolumn{1}{|c|}{ Model } & $\mathrm{t}$ & Sig. \\
\hline Constant & 0,17 & 0,987 \\
\hline Kualitas Website & 11,626 & 0,000 \\
\hline
\end{tabular}

Diketahui bahwa $\mathrm{t}$ hitung dari kualitas website memilki nilai thitung sebesar 11.626. Sementara untuk nilai signifikansi sebesar 0,050 serta df $=200-2=198, t_{\text {tabel }}$ yang diperoleh adalah sebesar $1.97202 \approx$ 1.972. Diketahui tingkat sehingga diperoleh nilai signifikansi lebih kecil dari nilai probabilitas $(0,050)$. Dapat disimpulkan bahwa $\mathrm{H}_{\mathrm{a}}$ diterima dan terdapat pengaruh positif dan signifikan secara parsial kualitas website terhadap penggunaan kembali pada website Tokopedia.

Tabel 10 Koefisien Determinasi

\begin{tabular}{|c|c|c|}
\hline Model & $\mathrm{R}$ & $\mathrm{R}^{2}$ \\
\hline 1 & 0,637 & 0,406 \\
\hline
\end{tabular}


Nilai koefisien determinasi atau ( $\mathrm{R}^{2} / \mathrm{R}$ Square) dari variabel kualitas website dengan penggunaan kembali dihasilkan nilai sebesar 0,406 .

Hasil ini menunjukkan bahwa kualitas website memberikan kontribusi pengaruh sebesar $40,6 \%$ terhadap penggunaan kembali. Sedangkan, sisanya sebesar 59,4\% merupakan konstribusi dari pengaruh variabel lainnya diluar dari variabel penelitian yang telah digunakan dalam penelitian ini.

\section{Pengaruh Kualitas Website Terhadap Penggunaan Kembali}

Berdasarkan hasil penelitian yang telah dilakukan, data dari hasil uji kolerasi, nilai kolerasi diantara variabel kualitas website terhadap penggunaan kembali sebesar 0,637 dengan arah hubungan positif. Selain itu diperoleh tingkat signifikansi sebesar 0,000 pada tingkat $0,351-0,800$. Menurut Saunders (2016) nilai korelasi yang berada pada rentang. Hal tersebut menunjukan bahwa kolerasi diantara kedua variabel sangat kuat atau dengan kata lain hubungan kualitas website terhadap penggunaan kembali sangat kuat dan memiliki hubungan yang positif.

Kemudian dilakukan uji regresi sederhana dengan hasil konstanta ( $\alpha)$ bernilai 0,045 dengan koefisien regresi (b) 0,381 yang diambil dari unstandardize coefficients beta sehingga muncul persamaan regresi sebagai berikut $\mathrm{Y}=$ $0,045+0,381 \mathrm{X}$. Dari persamaan regresi sederhana di atas dapat diketahui bahwa nilai konstanta adalah 0,045 dan koefisien regeresi menunjukkan angka 0,381. Dari persamaan tersebut menjelaskan bahwa jika tidak ada perubahan pada kualitas website atau $\mathrm{X}=0$ maka pengambilan keputusan yang dicapai sebesar 0,045 dan jika setiap peningkatan 1 unit kualitas website akan meningkatkan pengambilan keputusan sebesar 0,381. Apabila menggunakan standardized coefficient nilai koefisien regresi sebesar 0,637. Umar (2008) setelah nilai-nilai dari kolom $\mathrm{B}$ ditransfer menjadi satuan yang standar (standardized) di kolom beta, maka besar pengaruh pada variabel independen terhadap dependen dapat diketahui. Dari persamaan tersebut, jika tanpa variabel independen (X) yaitu kualitas website maka variabel dependen atau penggunaan kembali mempunyai nilai nol. Koefisien regresi (b) bernilai positif berarti jika terjadi penambahan satu satuan pada X maka akan meningkatkan Y sebesar (b) yaitu 0,637, dengan kata lain jika kualitas website ditingkatakan maka variabel penggunaan kembali akan meningkat pula begitupun sebaliknya.

Berdasarkan hasil koefisien determinasi diketahui bahwa nilai $\mathrm{R}$ Square adalah 0,406 dan nilai Adjust $\mathrm{R}$ Square adalah 0,405. Maka, dari angka-angka tersebut dapat diartikan bahwa kualitas website memiliki pengaruh sebesar $40,6 \%$ terhadap penggunaan kembali, dan sisanya sebanyak 59,4\% dipengaruhi oleh variabel lain yang tidak termasuk dalam penelitian ini. Simamarta (2009) dalam mengukur kualitas website dapat diukur pada beberapa kriteria yaitu; usabilitas, fungsionalitas, reliabilitas sistem, efisiensi, dan pemeliharaan. Selain itu menurut Mitch (2003) dalam mengukur kualitas website dapat digunakan metode $2 \mathrm{qcv} 3 \mathrm{q}$ yang dapat dijabarkan menjadi; qvis/quis (identitas), qvid/cuid (konten), cvr/cur (pelayanan), vbi/ubi (lokasi), qvando/quabdo(pemeliharaan),qvomodo/ qu quomodo (kegunaan), dan qvbvs avxiliis/quibus auxiliis (feasibilitas).

Hasil pada pegujian pengaruh kualitas website terhadap penggunaan kembali secara simultan dilakukan dengan menilai $\mathrm{f}$ hitung yang dihasilkan dari kedua variabel tersebut. Berdasarkan tabel uji f, diketahui bahwa $\mathrm{f}$ hitung dari kualitas website memilki nilai $t_{\text {hitung }}$ sebesar 135,154 . Sementara untuk nilai signifikansi sebesar 0,000 serta $\mathrm{df}=200-2=198, t_{\text {tabel }}$ yang 
diperoleh adalah sebesar 3,89. Diketahui tingkat sehingga diperoleh nilai signifikansi lebih kecil dari nilai probabilitas $(0,050)$. Dapat disimpulkan bahwa $\mathrm{H}_{\mathrm{a}}$ diterima dan terdapat pengaruh positif dan signifikan secara simultan kualitas website terhadap penggunaan kembali pada website Tokopedia.

Hasil yang sama juga dihasilkan pada pengujian pengaruh secara parsial. Berdasarkan uji t, t hitung yang didapat dengan signifikansi $\alpha=0,05$ dengan $\mathrm{df}=$ $200-2=198$. Dapat dilihat dari tabel tersebut bahwa nilai t hitung sebesar 11.626 sedangkan $\mathrm{t}$ tabel sebesar 1,98137. Hal tersebut menunjukkan bahwa t hitung lebih besar daripada t tabel. Dapat disimpulkan bahwa Ho ditolak dan Ha diterima, atau dapat diartikan bahwa terdapat pengaruh positif dan signifikan secara parsial antara kualitas website terhadap penggunaan kembali website Tokopedia. Karena probabilitas jauh lebih kecil dari 0,05 yaitu sebesar 0,000 maka model regresi dapat digunakan untuk memprediksi pengambilan keputusan atau dapat dikatakan bahwa kualitas berpengaruh terhadap penggunaan kembali.

Hubungan yang positif dan signifikan dalam peneltian ini dapat mendukung hasil penemuan pada penelitian terdahulu dimana pada penelitian yang dilakukan Sastika (2016), Afshan (2015) menyatakan hasil dari penelitian menunjukkan bahwa pengguna yang berinteraksi dengan manajemen dalam website tersebut akan menghasilkan kepuasan pengguna, mereka merasa adanya interaksi dengan organisasi melalui alat interaksi teknikal, evaluasi tidak hanya berpengaruh terhadap performa website organisasi tersebut namun juga dapat meningkatkan loyalitas elektronik. Hur, Ko dan Valacich (2011) menyatakan bahwa semakin tinggi kualitas website yang dimiliki oleh suatu perusahaan, maka semakin tinggi pula kepuasan elektronik yang dihasilkan dan apabila kepuasan elektronik semakin tinggi maka, loyalitas pengguna pada website tersebut juga semakin meningkat. Ayusuna (2015) menyatakan bahwa apabila perusahaan ingin meningkatkan transaksi yang dilakukan oleh pengguna dalam website perlu memperhatikan kualitas website yang dimiliki, dari hasil penelitiannya menunjukkan bahwa kemudahan dalam penggunaan website menjadi penentu pengguna melakukan pembelian berkesinambungan. Chen, Huang dan Davison (2016) kualitas informasi dan sistem mempengaruhi loyalitas pada pengunjung website, dari hasil tersebut website yang memiliki kualitas informasi dan sistem serta kualitas layanan pada website yang baik akan membuat pengguna loyal. Hubungan yang kuat pun terdapat dalam penelitian Wicaksono dan Susanto (2013) dimana kualitas website memiliki hubungan yang kuat terhadap kepuasan pengguna yang dapat berimplikasi terhadap loyalitas pengguna.

Hasil tersebut, apabila Tokopedia memiliki kualitas website yang sangat baik akan meningkatkan penggunaan kembali website. Kualitas website dapat membantu perusahaan dalam mencapai penggunaan kembali yang tinggi terutama pada website c-to-c e-commerce. Dengan hasil yang sudah baik namun, ada indikator yang berada level cukup pada kualitas website Tokopedia maka, perlu melakukan perbaikan pada kemudahan komunikasi kepada pihak manajemen. Hal tersebut menjadi pertimbangan utama untuk melakukan perbaikan pada kualitas website tokopedia yang perlu ditingkatkan kembali.

\section{KESIMPULAN DAN SARAN Kesimpulan}

1. Kualitas website Tokopedia dalam pandangan penggunanya berada pada tingkat yang tinggi/baik. Ditinjau dari nilai rata-rata variabel yang berada 
dalam kategori baik/tinggi dan ketiga dimensi yang memiliki nilai rata-rata tinggi/baik yaitu dimensi usability (kegunaan), information quality (kualitas informasi), dan service interaction quality (kualitas interaksi layanan). Hal ini menjadi anggapan bahwa kualitas website Tokopedia sudah baik dengan beberapa kriteria yang menunjukkan nilai yang baik/ tinggi

2. Penggunaan kembali website Tokopedia berada pada tingkat yang cukup, dengan hasil pada nilai rata-rata dalam kategori cukup. Hal ini ditinjau dari sepuluh indikator mendapatkan hasil yang cukup/cukup baik, dimana keseluruhan hasil dari indikator tersebut berada pada nilai rata-rata cukup/cukup baik.

3. Terdapat pengaruh yang positif dan signifikan antara kualitas website dan hasil pengaruh kualitas website terhadap penggunaan kembali secara parsial maupun simultan terdapat pengaruh positif dan signifikan. Dengan kata lain, jika kualitas website Tokopedia baik/ meningkat, maka penggunaan kembali website Tokopedia pun akan baik/meningkat. Berdasarkan nilai koefisien determinasi, pengaruh kualitas website terhadap penggunaan kembali menunjukkan nilai berkontribusi kualitas website Tokopedia sebesar $40,6 \%$ terhadap penggunaan kembali website Tokopedia, sementara sisanya sebesar 59,4\% dipengaruhi oleh faktorfaktor lain yang tidak diteliti dalam penelitian ini.

\section{Saran}

Kekurangan yang menjadi faktor penggunaan kembali yang cukup yaitu pada salah satu indikator pada kualitas website Tokopedia yaitu komunikasi kepada manajemen dengan mudah menjadi pertimbangan manajer melakukan perbaikan pada pelayanan pada website terutama pada bagian customer service yang mudah dijangkau sehingga pengguna lebih mudah untuk menjangkau dan memberikan tanggapan mengenai kualitas website maupun kualitas interaksi layanan website Tokopedia.

\section{DAFTAR PUSTAKA}

Afshan A. (2015). "Investigation of psychological dimensions of trust on e-loyalty: A case of Saudi Arabia consumers"., Journal of Islamic Marketing, Vol. 6 Issue: 2, pp.224249

Arikunto, S. (2014). Prosedur Penelitian: Suatu Penedekatan Praktik. Jakarta: Rineka Cipta

Asosiasi Penyelenggara Jasa Internet Indonesia. (2016). Infografis Penetrasi dan Perilaku Pengguna Internet Indonesia Survei 2016. apjii.or.id

Ayusuna, C., Ayusuna, E., \& Uslu, A. (2015). The Effects of Personality Traits and Website Quality on Online Impulse Buying. International Conference on Strategic Innovative Marketing, IC-SIM 2014, September $1-4,2014$

Barnes, S. J. \& Vidgen R. (2000). "WebQual: an exploration of Web site quality." European Conference in Information Systems, Vienna 2000.

Barnes, S. J. \& Vidgen R. (2002). "Assessing the quality of auction Web sites." Hawaii International Conference on Systems Sciences 2001.

Barnes, S. J. \& Vidgen R. (2001). "An evaluation of cyberbookshops: the WebQual method." International Journal of Electronic Commerce (6:1) 2001b, pp 11-30.

Barnes, S. J. \& Vidgen, R. (2003). Measuring Web site quality 
improvements: a case study of the forum on strategic management knowledge exchange". Industrial Management \& Data Systems, Vol. 103 Iss 5 pp. 297 - 309

Chen, X., Huang, Q., \& Davison, R. M. (2016). The role of website quality and social capital in building buyers'loyalty. International Journal of Information Management 1570 (2016) 12

Cox, B. G \& Koezler, W. (2004). Internet Marketing. New Jersey: Pearson Education, Inc

Flavian, C., Guinalı'u, M., \& Gurrea, R. (2005). The role played by perceived usability, satisfaction and consumer trust on website loyalty. Journal Information \& Management 43 (2006) 1-14 Elsevier B.V.

Ghozali, I. (2013). Aplikasi Analisis Multvariate dengan Program IBM SPSS 21. Semarang: Badan Penerbit Universitas Dipenogoro

Griffin, J. (2005). Customer Loyalty, Menumbuhkan danMempertahankan Kesetiaan Pelanggan. Jakarta : Erlangga

Hur, Y., Ko, Y. J., \& Valacich, J. (2011). A Structural Model of the Relationships Between Sport Website Quality, ESatisfaction, and E-Loyalty. Journal of Sport Management, 2011, 25, 458473 (C) 2011 Human Kinetics, Inc

Hurriyati, R. (2010). Bauran Pemasaran dan Loyalitas. Bandung: CV Alfabeta

Indrawati. (2015). Metode Penelitan Manajemen dan Bisnis : Korvergensi Teknologi Komunikasi dan Informasi. Bandung: Reftika Aditama

Jeon, M. M. \& Jeong, M. (2017). "Customers' perceived website service quality and its effects on eloyalty." International Journal of Contemporary Hospitality
Management, Vol. 29 Issue: 1,pp.438-457

Kotler, P. \& G. Armstrong. (2008). Prinsipprinsip Pemasaran. Edisi Bahasa Indonesia Jilid 1. Jakarta: Erlangga.

Laudon, K. C., \& Laudon, J. P. (2014). Management Information Systems: Managing The Digital Firm. Thirteenth Edition. Harlow: Pearson Education Limited

Loiacono, E.T., Watson, R.T. \& Goodhue, D.L. (2007). Webqual: An Instrument for Consumer Evaluation of Websites. International Journal of Electronic Commerce / Spring 2007, Vol. 11, No. 3, pp. 51-87

Lovelock, C. \& Wright. L.K. (2011). Manajemen Pemasaran Jasa Perspektif Indonesia. Jakarta: PT Indeks.

Lovelock, C. H. \& Wright, L. K. (2007). Manajemen Pemasaran Jasa. New Jersey: Prentice Hall

Maholtra, N. K. (2010). Marketing Research: An Applied Orientation Sixth Edition. New Jersey: Prentice Hall

Mason, R. \& Lind, D. D. (1996). Teknik Statistika Untuk Bisnis dan Ekonomi. Jakarta: Penerbit Erlangga. Alih Bahasa: Ellen Gunawan Sitompul.

Mich, L., Franch, M., \& Cilione, G. (2003). The $2 q c v 3 q$ Quality Model For The Analysis Of Web SiteRequirements. Journal of Web Engineering, Vol. 2, No.1\&2 (2003) 105-127 (C) Rinton Press

Nazir. M. (2011). Metode Penelitian. Bogor:Penerbit Ghalia Indonesia

Priyatno, D. (2013). Mandiri Belajar Analisis Data dengan SPSS. Yogyakarta: Mediakom

Santoso, S. (2015). Menguasai Statistik Multivariat. Jakarta: PT Elex Media Komputindo 
Santoso, S. (2012). Analisis SPSS Pada Statistik Parametrik. Jakarta: Elex Media Komputindo

Widya, S. (2016). Analisis Pengaruh Kualitas Website (Webqual 4.0) Terhadap Keputusan Pembelian Pada Website E-Commerce. Seminar Nasional Teknologi Informasi dan Komunikasi 2016 (SENTIKA 2016) ISSN: 2089-9815

Saunders, M., Lewis, P., \& Thornhill, A. (2016). Research Methods for Business Students: Seventh Edition. Harlow: Pearson Education Limited

Simarmata, J. (2009). Rekayasa Web. Yogyakarta: C.V Andi Offset

Supranto. (2011). Pengukuran Tingkat Kepuasan Pelanggan. Jakarta: PT Rineka Cipta

Tarigan, J. (2008). User Satisfaction Using Webqual Instrument: A Research on Stock Exchange of Thailand (SET). Jurnal Akuntansi dan Keuangan, Vol 10, No.1 Mei 2008: 34-47

Tjiptono, F. (2014). Pemasaran Jasa Prinsip, Penerapan, dan Penelitian. Yogyakarta: CV Andi Offset

Turban, E. (2004). Electronic Commerce 2004: A Managerial Perspective. New Jersey: Prentice Hall
TNS (Think with Google). (2015). ECommerce in Indonesia: More Shoppers Are Going to Mobile. apac.thinkwithgoogle.com Umar, Husein. (2008). Metode Penelitian untuk Skripsi dan Tesis Bisnis Edisi 2. Jakarta; PT Raja Grafindo Persada

We Are Social (Simon Kemp). (2016). Global Overview Digital In 2016. wearesocial.com

Wicaksono, B. L. \& Susanto, A. (2013). Evaluasi Kualitas Layanan Website Pusdiklat BPK RI Menggunakan Metode Webqual Modifikasian dan Importance Performance Analysis. JNTETI, Vol. 2, No. 2, Mei 2013 ISSN 2301 